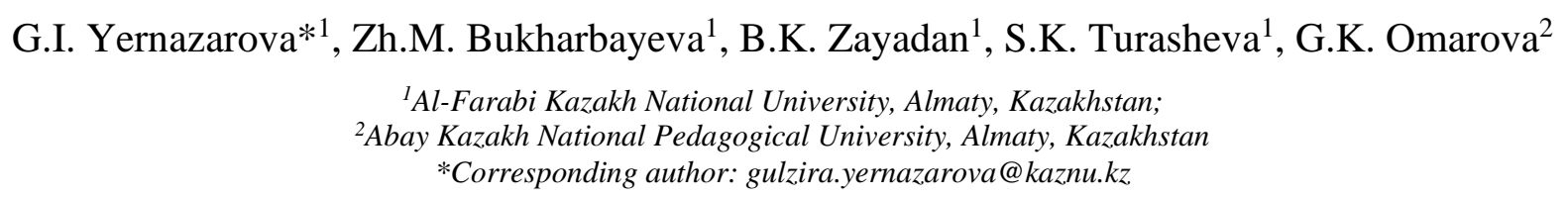

\title{
Development of technology for biological treatment of oily wastewater with a consortium of microorganisms, microalgae and aquatic plants
}

\begin{abstract}
The article describes the diversity of oil products that are the main sources of wastewater pollution. The dissolved or liquefied oil forms a floating layer on the water surface. The large emissions of different crude oil sources and household waste into the environment cause great damage to wildlife. It is evident that many types of oil sources are carcinogens. The article provides information on emissions of toxic compounds of industrial enterprises into the atmosphere and their adverse effects, including on human health because toxic compounds can cause many diseases. The methods of biotechnological treatment by mechanical, physicochemical and biological purification of water sources contaminated with oil waste are discussed. In particular, the importance of biological purification, petroleum technology, and microbiological purification and nanotechnological methods of water purification has been widely examined. The article contains information on water purification method using microalgae, biological filters, and wastewater treatment through aerotanks. Methods to purify phenolic compounds from wastewater such as adsorption, ion exchange, liquid-liquid extraction, chemical oxidation, electrochemical methods, solvent extraction, precipitation and biodegradation are considered. The role of some economically efficient and promising methods of bioremediation to eliminate and neutralize petroleum hydrocarbons and some pollutants in removing phenolic compounds is analysed.
\end{abstract}

Keywords: biological purification, microorganisms, microalgae, pollution, environment, biotechnology, phenol.

\section{Introduction}

Oil products are the most polluting substances in wastewater. It is very important to determine the content of pollutants in water sources. According to UNESCO data, unknown groups of hydrocarbons in oil, heating oil, kerosene, lube oils and their mixtures are among the top ten most dangerous pollutants in the world. Oil products can emulsify in solutions, dissolve and form a floating layer on the surface of water [1].

In the world the different technologies for widespread production, transportation and use of crude oil waste as clean energy source. Each stage of oil processing leads to oil spilling resulting in environment pollution. The introduction of crude oil, industrial pollutants and household waste into the ecosystem have a negative impact on the health of people, plants and animals, as most pollutants are carcinogenic. This is more than 0.005 billion deaths annually. Environmentally friendly and inexpensive treatment methods are needed to reduce, decompose or eliminate toxic contamination crude oil and industrial waste that affect the environment from wastewater [2].

Mainly contaminants enter the ecosystem through industrial wastewater and include pesticides, metabolites, pharmaceuticals, personal care products (PPCP), environmentally hazardous food additives and industrial waste such as nanometals. The resulting pollutants are usually not controlled, but may adversely affect the recipient's ecosystem [2].

Methods of collection and treatment of waste water from chemical impurities are systematically introduced at oil transport enterprises. Wastewater of oil transportation companies contains oil products, which can be used in the national economy after separation from water. However, water sources are contaminated with toxic compounds, including heavy metals [3].

Due to various industrial and household wastes, some heavy metals, such as cadmium $(\mathrm{Cd})$ and lead $(\mathrm{Pb})$, enter the water and contaminate the entire water system. Biomagnification in aquatic flora and fauna products is even more toxic due to the excessive flow of heavy metals into water sources in the form of non-ferrous plastics and electronic waste. These toxins cause many disorders in the human organism, for example, chromium IV is carcinogenic and very toxic in nature, and it causes many diseases, such as lung sensitization, nasal sinus cancer and skin ulcers [3]. 
Renal failure is caused by cadmium poisoning, as well as nervous disorders and mental retardation are associated with lead poisoning. The public is concerned about the negative impact on human health, which is directly related to the use of biota (seafood) contaminated with high concentrations of heavy metals [3].

Various acid-base reactions are important in water because their ions affect the chemical composition and $\mathrm{pH}$. Hydrogen ions are sufficient in an acidic medium, most of which consists of negatively charged ions, so there is little space left to bind heavy metals. Therefore, most heavy metals are soluble. The soluble forms of heavy metals are harmful because they are available to aquatic organisms and easy to transport. High levels of Biological Oxygen Demand (BOD) and Chemicals Oxygen Demand (COD) were caused by contamination of industrial facilities in northern Kashipur. The level of heavy metals $\mathrm{Cr}>\mathrm{Cd}>\mathrm{Pb}$ is recorded in river water samples. This is due to the fact that such pollution can be caused by the incineration of a large amount of industrial waste, agricultural waste, plastics and electronic waste. When examining river water samples it was found that water contains high concentrations of cadmium along with other toxic metals. Heavy metals are found in the kidneys of Channa punctatus fish. Fish kidneys are a good indicator of pollution as an object of study. During the cleaning phase the level of metal in the kidneys is high or may increase for some time, depending on the excretory function of the kidneys. This study showed high levels of $\mathrm{Cd}, \mathrm{Pb}$ and $\mathrm{Cr}$ in seafood. Lead poisoning can cause many diseases in children and adults, depending on the dose. It causes many problems, such as seizures, coma, kidney failure and high mortality rates, which do not significantly affect metabolism. Adults are more exposed to lead than children. The health effects of cadmium are exacerbated by human failure to release cadmium. High doses can cause severe irritation due to effects on the respiratory system. In addition, cadmium leads to chronic lung disease and testicular inflammation. One of the most toxic compounds in water sources is cadmium, because it is released into the environment due to high fuel consumption [3].

In addition, pollution of the environment of the Kazakhstan part of the Caspian Sea by heavy metals poses a threat not only to millions of inhabitants, but also to the flora and fauna of the Caspian $\mathrm{Sea} . \mathrm{Pb}$ and $\mathrm{Cd}$ in soil samples in Atyrau and Mangistau regions were within the normal limits, but samples from Aktau region exceeded the MAC (Maximum Permissible Concentration) for lead gleaned from these studies [4].

Biotechnological methods are very efficient and not hazardous in cleaning the environment and water sources from oil spills. The main biotechnological methods of oil waste control are bio sorption, microbiological and natural self-purification. Currently a large number of bio sorbents are produced, which differ in the variety of cultures and vectors of microorganism cultures immobilized on them. Various organic and mineral sorbents are used as carriers of microorganisms, such as activated carbon, zeolite minerals, etc. [5].

There are usually various types of mechanical, physicochemical and biological purification. Mechanical purification devices include sand traps, oil interceptors, sumps, flotation and filtration devices, etc. In these installations large dispersed impurities are removed. Physicochemical purification refers to flotation devices using chemical reagents and coagulants for colloidal impurities. Biological purification facilities include aeration tanks, bio filters, biological ponds and many others [2].

Biological method is universal for organic wastewater treatment. Microorganisms use various substances contained in wastewater as a source of nutrients in the metabolic process. The task of biological purification is the transformation of organic pollutants into harmless oxidation products $\mathrm{H}_{2} \mathrm{O}, \mathrm{CO}_{2}, \mathrm{NO}_{3}$, etc. The process of biochemical destruction of organic pollutants in waste treatment facilities is carried out under the influence of many simple microorganisms and bacteria. For the proper use of microorganisms in biological purification it is necessary to know the physiology of microorganisms, processes of nutrition, respiration, growth and reproduction [2].

Recovery and purification methods have proved their efficiency in decomposing certain contaminants. Although many microorganisms can decompose various pollutants, industrial wastewater purification schemes typically involve aerobic biological processes that have proved ineffectiveness due to poor biological degradation when used in combination with some pollutants. The current global challenge is to develop the most appropriate methods of waste control and disposal without compromising the environment. One way to remove oil waste from water sources is to use nanoparticles to reduce the amount of toxic compounds [2].

Nanotechnological methods used in water purification include coagulation and precipitation, adsorption, membrane filtration, photocatalysis and biological degradation (biodegradation of cenobiotics by microorganisms) and the processing of persistent pollutants. The risks of some pollutants to the environment and health have not yet been studied, so research is underway to find an effective way to combat health risks. The only option is to remove pollutants by physical, chemical and biological methods or toxic compounds from the environment [2]. 
The potential of nanoparticles from bulk solids has revolutionized recovery technology. Nanotechnologies are characterized by the use of small industrial particles in nanoscale $(<100 \mathrm{~nm})$ in the structure of nanoparticles. Nanoparticles are widely used to restore contaminated soil and contaminated water. They can appear naturally or in the form of special materials and random byproducts in production processes [2].

Biosynthetic nanoparticles are used as effective sorbents for contaminants. Environmental additives include indoor and outdoor air purification, water and wastewater treatment, soil and groundwater treatment. Land, air and water treatment with nanomaterials provide efficient and inexpensive methods of cleaning the environment due to the rapid reaction of nanoparticles and their treatment. Thermally activated persulfate can effectively break down tricsolan (TCS) in the soil. TCS is used to determine the amount of toxic compounds and microbial activity in the soil. For example, nitrogen cycling in soil is disturbed by exposure to a TCS concentration of $10 \mathrm{mg} / \mathrm{kg}$. Nanoparticles in soil repair often use nanometer length scale zero-valent iron in decomposition of halogenated organic compounds. Nanoscale calcium peroxide is used to remove organic matter from the soil, while crude oil, including gasoline and nanoscale metal oxides, is also useful for absorbing metals from the environment [2].

Each living organism differs from the non-living organism by the presence of metabolism, which includes the absorption of nutrients and excretions. The main metabolic processes are nutrition and breathing. Biochemical treatment of industrial wastewater containing oil products is carried out in air filters (biofilters), aerotanks and biological ponds [6].

Green chemistry is an entirely new branch of environmental chemistry that is designed to help researchers find green alternatives to existing chemicals through solvents, energy use, toxicity, etc. Paul T. Anastas and John K. Warner developed this method, and then 12 principles of green chemistry were created. Water sources contaminated with some heavy metals (for example, chromium) can be purified by microalgae and aquatic plants [6-8].

Purification of water with microalgae is a method based on biocatalysis. Many studies have shown that urban wastewater, as well as industrial wastewater and agricultural wastewater, can be treated with microalgae because microalgae reduce COD and BOD, kill E. coli bacteria, and use phosphorus and nitrogen as energy sources. In addition, the unique methodology of the study includes environmental assessment. Evaluation is a systematic study of the method in accordance with 12 principles of green chemistry, and an assessment of stability shows compliance with these principles. It is recommended to clean water and soil from oil residues by microbiological methods. It is distinguished by the genetic stability of microorganisms, storage viability, and the ability to quickly remove many toxic compounds $[6,9]$.

Biofilters are tanks made of reinforced concrete or brick, the bottom of which is filled with filtering materials and irrigated with waste water. Slag, gravel, plastic etc. used to load biofilters. Treatment of wastewater in biofilters is carried out under the influence of microorganisms that fill the water surface and form a biological film. Microorganisms separate organic substances from water upon contact of wastewater with this film [1].

Treatment of wastewater through aerotanks is carried out under the influence of clusters of microorganisms (active sludge). Aerotanks are reinforced concrete tanks 30-100 m or more in length, 3-10 m wide and 3-5 m deep. Air and nutrients are delivered to aerotanks for normal life. Advantages of biological treatment for removal of various organic compounds from waste water, including toxic ones, are simplicity of equipment design and relatively low cost of operation. The disadvantages of using aerotanks include high capital costs, strict compliance with the treatment process, the toxic effect of some organic compounds on microorganisms, and the need to dilute wastewater in the presence of high concentrations of impurities. In the production of oil products some reagents cause corrosion damage; solutions of alkali, phenolic acid, ketones, furfurol, sulfur are used in the processing of crude oil. However, these oil wastes also contain a small amount of phenolic compounds. Phenol content in oil reaches $0.1 \%$. Water sources are often contaminated with phenolic compounds during the extraction of important compounds from oil products. Therefore it is important for water sources to be purified from phenolic compounds [1].

The main pollutant in the world is phenol, which is absorbed differently into aquatic and terrestrial ecosystems. Due to its high toxicity at low concentrations and water-soluble properties, it easily accumulates in the food chain and has adverse effects on flora, fauna and humans. Phenol and its derivatives are often found in wastewater of some industries such as coal tar, pharmaceuticals, pesticides, fertilizers, antiseptic lotions, leather plants, paper and cellulose. Phenol can be harmful when inhaled, touched or swallowed; for example, it causes severe eye irritation, respiratory diseases, and muscle spasms in animals. After a long period high 
levels of phenol can cause serious damage to the heart, kidneys, liver and lungs. Treatment of wastewater and water uses different disposal methods (biological, chemical and physical) due to negative effects of phenol [7].

Methods such as adsorption, ion exchange, liquid extraction, chemical oxidation, electrochemical methods, solvent extraction, precipitation and biodegradation are used to remove phenol from aqueous solutions. In recent years biological processes (bio sorption and bio degradation) have attracted a lot of attention as an inexpensive but effective, flexible and environmentally friendly alternative. In particular, the biodegradation method is usually used in the treatment of organic pollutants, since it allows the decomposition of compounds into inorganic mineral components. A large number of natural microorganisms, including bacteria, fungi and algae, are capable of bio sorption and decomposing phenol. There are many studies on the degradation of phenol by bacteria and fungi [7].

Many strains of bacteria decomposing phenol have been genetically identified and isolated. The Pseudomonas and Bacillus families of bacteria are widely used in the study of phenol biodegradation. Bayramoglu and colleagues showed that $F$. trogii (fungi species) are able to degrade and bio sorb phenol and 2-chlorophenol. Stoilova and others noted that a strain of Aspergillus awamori NRRL 3112 fungi could decompose large amounts of phenol. Several additional studies have been conducted on the degradation of phenolic compounds by algae, which have proved that algae also decomposes phenols. Kelknar and Kosarnik tested that Chlorella sp., Scenedesmus obliquus and Spirulina maxima can cleave phenol as a carbon source in a carbon-free environment. Sargassum muticum (brown algae) was used to effectively purify phenol, 2-chlorophenol and 4-chlorophenol [7].

This study aims to investigate the effectiveness of phenol removal by viable Scenedesmus regularis. After incubation of phenol with S. regularis, High Pressure Liquid Chromatography (HPLC) determined the residual phenol concentration with a retention time 4.0 minutes. Calibration curve is obtained from basic standard solutions of phenol $(5,10,25,50$ and $100 \mathrm{ppm})$. The ratio of linear to reproductive correlations exceeded $99 \%$. The dependence was linear and exceeded $99 \%$ of the correlation coefficients, which indicates the purity of the analytical results. The calculated limits of detection (LOD) and quantification (LOQ) values were 91.3 and $30.1 \mathrm{ppb}$. For the accuracy of sample analysis the measurement of the known phenolic standard concentration $(30 \mathrm{ppm})$ is accompanied by standard measurements. Standard deviation and relative standard deviation of the phenol sample were $30.19 \mathrm{ppm}, 0.55 \mathrm{ppm}$ and $1.83 \%$. After the biodegradation process the phenol peak is completely lost or its intensity decreased. This result showed that Scenedesmus regularis completely removes all phenols. It is known that purification of contaminants by biological materials can occur through three processes: biodegradation, biosorption and bioaccumulation. When the main absorption peak of the molecule disappears or a new peak appears, the removal process usually occurs due to biodegradation [7].

Bioremediation is a process of decomposition of organic substances based on the natural ability of soil microorganisms to eliminate environmental pollutants. Bioremediation is a cost-effective and promising biotechnological approach that eliminates or neutralizes various pollutants, including petroleum hydrocarbons, and raises concerns about natural biological activity. It has advantages over methods of detoxification or decomposition of pollutants in the environment [2].

\section{Bioremediation as cleaning technology}

There are several ways to clean the contaminated environment but biological treatment is the most reliable, affordable and economical strategy. Bioremediation is the ecologically safe and effective method of restoration based on science about biodegradation, which uses ability of bacteria completely to delete pollutants from environment or to reduce their quantity to safe amounts at the expense of mineralization. Bioremediation provides complete conversion or removal of organic compounds and is the best way to clean the environment even at low concentrations and crude oil contamination. According to Wolejko et al., microbiological disinfection of contaminated media is an effective alternative to physicochemical treatment. The use of improved bioremediation technology adds nutrients to eliminate certain contaminants that are rapidly decomposed by bacteria, or to facilitate the rate of decomposition $[2,10]$.

Bioremediation is a process involving a number of technologies that destroy organic compounds of natural or established microorganisms. Although the science of bioremediation is simple, the design and implementation of a rehabilitation programme requires considerable experience and knowledge [2].

Therefore, advances in science and technology such as manipulation, design, and application of various input parameters are very important for increasing the rate of biodegradation. Efficiency of bioremediation treatment is reduced depending on environmental factors, properties of contaminants and soil matrix [2]. 
Bio stimulation involves manipulating abiotic factors to increase the rate of nutrient uptake to eliminate local contaminants or to stimulate the destructive capacity of microorganisms. Bio stimulation is carried out only in the presence of local microorganisms capable of degradation, but its speed is slow and needs to be increased. Studies have shown that the addition of nutrients to the contaminated environment stimulates biodegradation by increasing microbial biomass, which dramatically increases the rate of removal of crude oil. However, the optimum concentration and types of nutrients required for active decomposition of pollutants vary considerably depending on soil conditions. Excessive concentrations of nutrients in the ecosystem can also cause toxic reactions [2].

\section{Conclusions}

The study showed that various seafood organizations found that the level of metals in some seafood exceeded the permissible level for human consumption. The results showed that the kidneys of common edible fish Channa punctatus showed contamination of the aquatic environment with heavy metals, as well as, according to the World Health Organization, exceeded the established limit in water.

During cultivation in model microalgae and some aquatic plants, the absorption of chromium increases with increasing metal concentration. During the cultivation microalgae and some aquatic plants in the model run, chromium sorption increased with increasing metal concentrations. These experimental results show the further use of water crops for the treatment of wastewater contaminated with various pollutants, including heavy metals and oil waste.

In the future it is planned to carry out experimental work designed to purify wastewater from oil and oil products using some aquatic plants and algae.

\section{References}

1 Лазарев В.В. Проблемы нефтяных загрязнений вод и способы их очистки / В.В. Лазарев, М.И. Кучер, Е.Э. Френкель. - Вольск: Вольский воен. ин-т матер. обеспечения, 2017. - 145 с.

2 Okoh E. Clean-up of crude oil-contaminated soils: bioremediation option / E. Okoh, Z.R. Yelebe, B. Oruabena, E.S. Nelson, O.P. Indiamaowei // International Journal of Environmental Science and Technology. — 2018. https://doi.org/10.1007/s13762-01902605-y

3 Idrees N. Evaluation of Some Heavy Metals Toxicity in Channa punctatus and Riverine Water of Kosi in Rampur, Uttar Pradesh, India / N. Idrees, R. Sarah, B. Tabassum, E. Fathi Abd Allah // Saudi Journal of Biological Sciences. - 2020. https://doi.org/10.1016/j.sjbs.2020.03.002

4 Akimbekov N.Sh. Microbial Load as Ecotoxicological Assessment of Heavy Metals Presence in Soil Samples from the Kazakhstan Part of the Caspian Sea / N.Sh. Akimbekov, A.K. Yernazarova, K.T. Tastambek, G.Zh. Abdieva, P.S. Ualieva, G.K. Kaiyrmanova, L.B. Djansugurova, A.A. Zhubanova // Eurasian Chemico-Technological Journal. — 2017. — Vol. 19. — P. 335-340.

5 Губкина Т.Г. Биотехнологический способ очистки воды и почвы от загрязнения нефтепродуктами / Т.Г. Губкина, К.В. Украинская, Н.В. Фокина, В.А. Мязин // Современные проблемы загрязнения почв: IV Междунар. науч. конф. - М.: Изд-во МГУ, 2013. - 165 с.

6 Oktor K. Treatment of Baker's Yeast Wastewater with Freshwater Microalga and Its Green Chemistry Evaluation / K. Oktor // Hacettepe J. Biol. \& Chem. - 2018. - Vol. 46 (3). - P. 457-463.

7 Gökben B.K. Investigation on phenol degradation capability of Scenedesmus regularis: Influence of process parameters / B.K. Gökben, A.Ü. Metin, Y. Aluç // Environmental Technology. — 2018. — Vol. 145. — P. 1145-1154.

8 Yernazarova G. Effect of chromium and other HM on microalgae / G. Yernazarova, S. Turasheva, G. Omarova // Bulletin of al-Farabi Kazakh National University. — 2017. — Vol. 71, No. 2. — P.42-49.

9 Казанкапова М.К. Создание модифицированных углеродминеральных сорбентов для очистки природных объектов от техногенных загрязнений: дис. ... д-ра PhD / М.К. Казанкапова. - Алматы, 2013. — 145 с.

10 Moinuddin A. Bioremediation plan for oil contaminated soils / A. Moinuddin, S. Tasleem, A. Khan // Bioscience Research. 2018. — Vol. 15 (4). - P. 3531-3536.

11 Горелая О.Н. Магнитный сорбент из отходов водоподготовки для очистки нефтесодержащих сточных вод / О.Н. Горелая, В.И. Романовский // Вестн. Брест. гос. техн. ун-та. — 2020. — № 2. — С. 62-64. 
Г.И. Ерназарова, Ж.М. Бухарбаева, Б.К. Заядан, С.К. Турашева, Г.К. Омарова

\title{
Мұнаймен ластанған ағынды суларды микроорганизмдер, микробалдырлар және су өсімдіктерінің консорциумынан биологиялық тазарту технологиясын жасау
}

\begin{abstract}
Мақалада мұнай өнімдерінің алуан түрлілігі туралы айтылған, ағын суларды ең көп ластайтын мұнай көздері болып табылады. Мұнайдың таралуы еріген немесе бос күйде, су бетінде қалқымалы қабат түзеді. Мұнай шикізат көздерінің алуан түрлілігі және тұрмыстық қалдықтардың сыртқы ортаға көп мөлшерде бөлінуі нәтижесінде тірі табиғатқа үлкен нұқсан келтіруде. Сондықтан, мұнай көздерінің көп түрлері канцерогенді болып табылады. Авторлар мақалада өндірістік қондырғылардан шыққан уытты қосылыстардың ауаға таралуы және олардың жағымсыз әсер етуі туралы мәліметтер келтірген. Уытты қосылыстардың әсерінен көптеген кездейсоқ аурулардың пайда болу ықтималдығы өте жоғары екендігі туралы айтылған. Мұнай қалдықтармен ластанған су көздерін биотехнологиялық әдістерді пайдалана отырып, тазарту тәсілдері келтірілген. Мұндағы, механикалық, физика-химиялық және биологиялық тазартулардың түрлері қарастырылған. Әсіресе, биологиялық тазартудың маңызы, қайта өңдеу технологиясы, микроорганизмдер көмегімен тазарту әдісі және суды тазартуда қолданылатын нанотехнологиялық әдістерге кеңінен тоқталған. Суды микробалдырлар арқылы тазарту тәсілі, биосүзгілер көмегімен тазарту және ағын суларды аэротенктер арқылы тазарту үдерісі туралы мәліметтер жинақталған. Ағын су құрамындағы фенолды қосылыстардан тазарту үшін адсорбция, ион алмасу, сұйық сұйықтықты экстракциясы, химиялық тотығу, электрохимиялық әдістер, еріткіштерді алу, тұндыру және биодеградация сияқты әдістер талқыланған. Және де фенолды косылыстарды жоюда кейбір микробалдырлардың маңызы қарастырылған. Мұнай көмірсутектері мен кейбір ластаушы заттарды жою және оларды бейтараптандыру үшін экономикалық тиімді және болашағы зор биоремедиация тәсілі туралы мәліметтер келтірілген.
\end{abstract}

Кілm сөздер: биологиялық тазарту, микроорганизмдер, микробалдырлар, ластану, қоршаған орта, биотехнология, фенол.

\section{Г.И. Ерназарова, Ж.М. Бухарбаева, Б.К. Заядан, С.К. Турашева, Г.К. Омарова Разработка технологии биологической очистки
нефтесодержащих сточных вод с помощью консорциума
микроорганизмов, микроводорослей и водных растений}

В статье рассмотрено разнообразие нефтепродуктов, которые являются основными источниками загрязнения сточных вод. Распространение нефти в растворенном или разжиженном виде образует плавающий слой на поверхности воды. В результате больших выбросов разнообразных источников сырой нефти и бытовых отходов в окружающую среду наносится огромный ущерб дикой природе. Потому что многие виды источников нефти являются канцерогенами. В статье представлена информация о выбросах в атмосферу токсичных соединений промышленных предприятий и их неблагоприятных последствиях. А также токсичные соединения могут вызывать множество случайных заболеваний. Существуют методы очистки загрязненных нефтеотходами водных источников с использованием биотехнологических методов. Авторами изучены виды механической, физико-химической и биологической очистки. В частности, широко обсуждалась важность биологической очистки, технологии переработки, микробиологической и нанотехнологической методов очистки воды. Собрана информация о способе очистки воды с помощью микроводорослей, биофильтрами и очистке сточных вод через аэротенки. Обсуждены такие методы, как адсорбция, ионный обмен, жидкостно-жидкостная экстракция, химическое окисление, электрохимические методы, экстракция растворителем, осаждение и биодеградация для очистки фенольных соединений из сточных вод. Рассмотрена роль некоторых микроводорослей в удалении фенольных соединений. Приведена информация об экономических эффективных и перспективных методах биоремедиации для устранения и обезвреживания нефтяных углеводородов и некоторых загрязняющих веществ.

Ключевые слова: биологическая очистка, микроорганизмы, микроводоросли, загрязнение, окружающая среда, биотехнология, фенол.

\section{References}

1 Lazarev, V.V., Kucher, M.I., \& Frenkel, E.E. (2017). Problemy neftianykh zagriaznenii vod i sposobi ikh ochistki [Problems of oil pollution of waters and methods of their treatment]. Volsk: Volskii institute of material support [in Russian]. 
2 Okoh, E., Yelebe, Z.R., Oruabena, B., Nelson, E.S. \& Indiamaowei, O.P. (2018). Clean-up of crude oil-contaminated soils: bioremediation option. International Journal of Environmental Science and Technology, https://10.1007/s13762-019-02605-y

3 Idrees, N., Sarah, R., Tabassum, B., \& Fathi Abd Allah, E. (2020). Evaluation of Some Heavy Metals Toxicity in Channa punctatus and Riverine Water of Kosi in Rampur, Uttar Pradesh, India. Saudi Journal of Biological Sciences https://doi.org/10.1016/j.sjbs.2020.03.002

4 Akimbekov, N.Sh., Yernazarova, A.K., Tastambek, K.T., Abdieva, G.Zh., Ualieva, P.S., \& Kaiyrmanova, G.K., et al. (2017). Microbial Load as Ecotoxicological Assessment of Heavy Metals Presence in Soil Samples from the Kazakhstan Part of the Caspian Sea. Eurasian Chemico-Technological Journal, 19; 335-340.

5 Gubkina, T.G., Ukrainskaia, K.V., Fokin, N.V., \& Myazin, V.A. (2013). Biotechnologicheskii sposob ochistki vody i pochvy ot zagriazneniia nefteproduktami [Biotechnological method of water and soil purification from oil pollution]. The modern problems of soil pollution: IV Mezhdunarodnaia nauchnaia konferentsiia - IV International scientific conference (p. 165). Moscow: MSU Publ. [in Russian].

6 Oktor, K. (2018). Treatment of Baker's Yeast Wastewater with Freshwater Microalga and Its Green Chemistry Evaluation. Hacettepe J. Biol. \& Chem., 46 (3), 457-463.

7 Gökben, B.K., Metin, A.U., \& Aluç, Y. (2018). Investigation on phenol degradation capability of Scenedesmus regularis: Influence of process parameters. Environmental Technology, 145; 1145-1154.

8 Yernazarova, G., Turasheva, S., \& Omarova, G. (2017). Effect of chromium and other HM on microalgae. Bulletin of al-Farabi Kazakh National University, 71 (2); 42-49.

9 Kazankapova, M.K. (2013). Sozdanie modifitsirovannykh uglerodmineralnykh sorbentov dlia ochistki prirodnykh obektov ot tekhnogennykh zagriaznenii [Creation of modified carbon-mineral sorbents for cleaning natural objects from technogenic pollution]. $P h D$ Thesis [in Russian].

10 Moinuddin, A., Tasleem, S., \& Khan, A. (2018). Bioremediation plan for oil contaminated soils. Bioscience Research, 15(4); 3531-3536.

11 Gorelaia, O.N., \& Romanovsky, V.I. (2020). Magnitnyi sorbent iz otkhodov vodopodgotovki dlia ochistki neftesoderzhashchikh stochnykh vod [Magnetic sorbent from water treatment waste for oily waste water treatment]. Vestnik Brestskogo gosudarstvennogo tekhnicheskogo universiteta - Bulletin of Brest State Technical University, 2, 62-64 [in Russian]. 